\title{
Molecular evidence of two cryptic species of Stramonita (Mollusca, Muricidae) in the southeastern Atlantic coast of Brazil
}

\author{
Juliana Beltramin De Biasi ${ }^{1}$, Acácio Ribeiro Gomes Tomás ${ }^{2}$ and Alexandre Wagner Silva Hilsdorf ${ }^{1}$ \\ ${ }^{1}$ Núcleo Integrado de Biotecnologia, Universidade de Mogi das Cruzes, Mogi das Cruzes, SP, Brazil. \\ ${ }^{2}$ Centro Avançado de Pesquisa Tecnológica do Agronegócio do Pescado Marinho, Instituto de Pesca, \\ Santos, SP, Brazil.
}

\begin{abstract}
Snails of the genus Stramonita are commonly found in the rocky intertidal habitat of the western Atlantic Ocean coast. They belong to a monophyletic taxon that occurs along the tropical and warm-temperate Atlantic and eastern Pacific rocky shores. This genus comprises different valid species and members of the S. haemastoma complex. In the present study, samples of Stramonita were collected from three different regions of southeastern Brazil. Partial sequences of two mitochondrial genes, $\mathrm{COI}$ and $16 \mathrm{~S}$ rRNA, were used to compare nucleotides sequences between Stramonita specimens. Levels of nucleotide divergence greater than $2 \%$ across the three sampled regions were used for differentiation at the species level. One of the identified species was $S$. brasiliensis, which has recently been described by molecular analysis; the other species may represent $S$. haemastoma, not yet described in the southeastern Brazilian coast.
\end{abstract}

Keywords: COI, 16s rRNA, mitochondrial DNA, southern oyster drill, Brazilian coast.

Received: August 4, 2015; Accepted: January 27, 2016.

In marine environments, genetically different organisms may arise due to ecological, geological, and oceanographic barriers under either allopatric, parapatric or even sympatric models of evolution (Rocha et al., 2005; Von der Heyden et al., 2011). Cryptic species indistinguishable by morphological criteria are often classified within a single taxon (Bickford et al., 2007). The existence of cryptic species seems to be common in marine organisms, such as in Sciaenidae fishes (Vinson et al., 2004; Santos et al., 2006), as well as in numerous invertebrates (Thorpe et al., 2000), including Penaeid shrimp (Gusmão et al., 2005). Although not regarded as cryptic species, some species of the genus Stramonita contain features which make identification challenging; these features are characterized by a wide range of ecophenotypic variations, which can be corroborated by the morphology and coloration variability of the shell due to environmental factors (Butler, 1985; Houart and Gofas, 2010). As a result, these species have been misidentified, which has led to taxonomic controversy (Liu et al., 1991; Vermeij, 2001).

Stramonita, also known as southern oyster drill, is a predatory marine gastropod mollusc found along rocky intertidal habitats of the Atlantic and eastern Pacific

Send correspondence to Alexandre Wagner Silva Hilsdorf. Universidade de Mogi das Cruzes, Núcleo Integrado de Biotecnologia, PO Box 411, 08780-911, Mogi das Cruzes, SP, Brazil, Email: wagner@umc.br
Oceans (Ramírez et al., 2009). Due to variation in shell shape and coloration, the two S. haemastoma and S. rustica are divided into three subspecies: Stramonita haemastoma floridana in the Caribbean, Stramonita haemastoma canaliculata in the Gulf of Mexico, and Stramonita rustica bicarinata on the South Atlantic islands (Clench, 1947; Butler, 1985; Harding and Harasewych, 2007).

Mitochondrial gene sequences have been used in molecular taxonomy studies of diverse marine life forms (Knowlton, 2000; Bucklin et al., 2011; Trivedi et al., 2015). Molecular characterization using mitochondrial DNA has been carried out for different gastropod group taxa (Donald et al., 2005; Pfenninger et al., 2006; Perez and Minton, 2008; Kool and Galindo, 2014).

Here, we evaluated individuals of the genus Stramonita sharing the same rocky intertidal habitats, assuming that: (i) both putative species show subtle morphological differentiation; (ii) there is no report of the presence of two species of Stramonita along the southern coastline of Brazil; (iii) the sustainable use of this marine resource under exploitation by coastal fishing communities depends on accurate species identification. Therefore, in the present work we aimed to assess the likely presence of two sympatric species, and to discuss the implications of the outcomes for conservation of these ecologically important intertidal marine snails. 
Table 1 - Sampling locations, geographic coordinates, Genbank access number, and morphological identification of the Stramonita individuals.

\begin{tabular}{|c|c|c|c|c|c|}
\hline \multirow[t]{2}{*}{ Location } & $\mathrm{COI}$ & $16 \mathrm{~S}$ & \multirow{2}{*}{ Coordinates } & \multirow{2}{*}{ Morphological identification } & \multirow[t]{2}{*}{ Molecular identification } \\
\hline & GenBank access $\mathrm{n}$. & GenBank access $n$. & & & \\
\hline \multirow[t]{8}{*}{ Peruíbe } & KM655935 & KM655959 & $24^{\circ} 19^{\prime} 2^{\prime \prime} \mathrm{S} 46^{\circ} 59^{\prime} 44^{\prime \prime W}$ & S. floridana & S. brasiliensis \\
\hline & KM655936 & KM655960 & & S. floridana & S. brasiliensis \\
\hline & KM655937 & KM655961 & & S. haemastoma & S. brasiliensis \\
\hline & KM655941 & KM655965 & & S. floridana & S. brasiliensis \\
\hline & KM655948 & KM655972 & & S. haemastoma & S. brasiliensis \\
\hline & KM655954 & KM655978 & & S. haemastoma & S. cf. haemastoma \\
\hline & KM655955 & KM655979 & & S. haemastoma & S. cf. haemastoma \\
\hline & KM655957 & KM655981 & & S. haemastoma & S. cf. haemastoma \\
\hline \multirow[t]{6}{*}{ Ilha Bela } & KM655938 & KM655962 & $23^{\circ} 46^{\prime} 28^{\prime \prime} \mathrm{S} 45^{\circ} 21^{\prime} 20^{\prime \prime} \mathrm{W}$ & S. floridana & S. brasiliensis \\
\hline & KM655940 & KM655966 & & S. haemastoma & S. brasiliensis \\
\hline & KM655942 & KM655967 & & S. floridana & S. brasiliensis \\
\hline & KM655943 & KM655971 & & S. floridana & S. brasiliensis \\
\hline & KM655953 & KM655977 & & S. haemastoma & S. cf. haemastoma \\
\hline & KM655956 & KM655980 & & S. haemastoma & S. cf. haemastoma \\
\hline \multirow[t]{6}{*}{ Santos } & KM655939 & KM655963 & $23^{\circ} 57^{\prime} 52^{\prime \prime} \mathrm{S} 46^{\circ} 20^{\prime} 0^{\prime \prime} \mathrm{W}$ & S. floridana & S. brasiliensis \\
\hline & KM655944 & KM655968 & & S. haemastoma & S. brasiliensis \\
\hline & KM655945 & KM655969 & & S. floridana & S. brasiliensis \\
\hline & KM655946 & KM655970 & & S. floridana & S. brasiliensis \\
\hline & KM655952 & KM655976 & & S. haemastoma & S. cf. haemastoma \\
\hline & KM655958 & KM655982 & & S. haemastoma & S. cf. haemastoma \\
\hline
\end{tabular}

Twenty individuals of Stramonita were randomly sampled at three regions along the State of São Paulo coast, Brazil: Ilha Bela $\left(23^{\circ} 48^{\prime} \mathrm{S}, 45^{\circ} 21^{\prime} \mathrm{W}\right)$, Santos $\left(23^{\circ} 59^{\prime} \mathrm{S}\right.$, $\left.46^{\circ} 18^{\prime} \mathrm{W}\right)$, and Peruíbe ( $\left.24^{\circ} 21^{\prime} \mathrm{S}, 46^{\circ} 60^{\prime} \mathrm{W}\right)$. The identification of putative species was performed using subtle morphological variations based on Clench (1947), Rios (1994), and Matthews (1968). DNA was extracted from the foot muscle using the IlustraTM Tissue \& Cells genomic Prep Mini Spin Kit (GE Healthcare Life Sciences, Buckinghamshire, UK) following the manufacturer's instructions. The partial region of the genes $16 \mathrm{~S}$ ribosomal RNA (or 16S rRNA) and cytochrome c oxidase subunit I (or COI) were amplified using PCR. The primer pairs used for the 16S rRNA gene amplification were: 16Sar-L (5-CGCCTGTTTAACAAAAACAT-3) and 16Sbr-H (5-CCGGTTTGAACTCAGATCACGT-3) (Palumbi, 1996). The primers used for the amplification of the COI gene were: dgLCO1490 (5- GGTCAACAAATCATAAA GAYATYGG-3) and dlHCO2198 (5- TAAACTTCAGGG TGACCAAARAAYCA-3) (Meyer, 2003). PCR amplifications were performed in a final volume of $50 \mu \mathrm{L}$. Each reaction contained a buffer of PCR $1 \mathrm{X}, 100 \mathrm{mMdNTPs}, 2.5$ $\mathrm{mM}$ of $\mathrm{MgCl} 2,0.5 \mu \mathrm{M}$ of each primer, $1 \mathrm{U} / \mu \mathrm{L}$ Taq DNA Polymerase (Invitrogen ${ }^{\mathrm{TM}}$, Carlsbad, USA), deionized water, and $50 \mathrm{ng} / \mu \mathrm{L}$ of genomic DNA. The thermal regime for the 16S rRNA consisted of an initial denaturalization to 94 ${ }^{\circ} \mathrm{C}$ for $1 \mathrm{~min}$, followed by 35 cycles at $94{ }^{\circ} \mathrm{C}$ for $30 \mathrm{sec}, 52$
${ }^{\circ} \mathrm{C}$ for $30 \mathrm{sec}$, and $72{ }^{\circ} \mathrm{C}$ for $1 \mathrm{~min}$, with a final extension at $72{ }^{\circ} \mathrm{C}$ for $10 \mathrm{~min}$. PCR conditions for the COI gene included initial denaturalization at $94^{\circ} \mathrm{C}$ for $1 \mathrm{~min}$, followed by 30 cycles at $94{ }^{\circ} \mathrm{C}$ for $30 \mathrm{~s}, 45^{\circ} \mathrm{C}$ for $40 \mathrm{~s}$, and $72{ }^{\circ} \mathrm{C}$ for 1 min, with a final extension at $72{ }^{\circ} \mathrm{C}$ for $10 \mathrm{~min}$. PCR products were purified and sequenced in an automatic $\mathrm{ABI} 3700$ sequencer (PE Applied Biosystems, Foster City, CA).

All sequences were confirmed by sequencing both strands. The consensus sequence for the two strands was obtained using CodonCode Aligner v.2.0.4 software (CodonCode Corporation, Dedham, Massachusetts, USA). Sequences were aligned using the Clustal W interface with the Mega 5 software (Tamura et al., 2011). The saturation levels of the molecular data were determined using DAMBE software version 5.0.39 (Xia and Xie, 2001). Transition and transversion were plotted based on the TN93 model from each gene data set (Tamura and Nei, 1993). Distance estimates of genetic divergence (p-distance) over sequence pairs, between and within groups, were conducted with MEGA 5. The phylogenetic trees were built by Maximum Likelihood (ML) carried out with MEGA 5, based on alignments of concatenated COI and 16S rRNA genes. Modeltest 3.7 (Posada and Crandall, 1998) was applied to find the best fitted model for ML. The consistency of topologies was measured by the bootstrap method (1000 replicates) and only confidence values $>$ $50 \%$ were reported. To compare the Stramonita species se- 


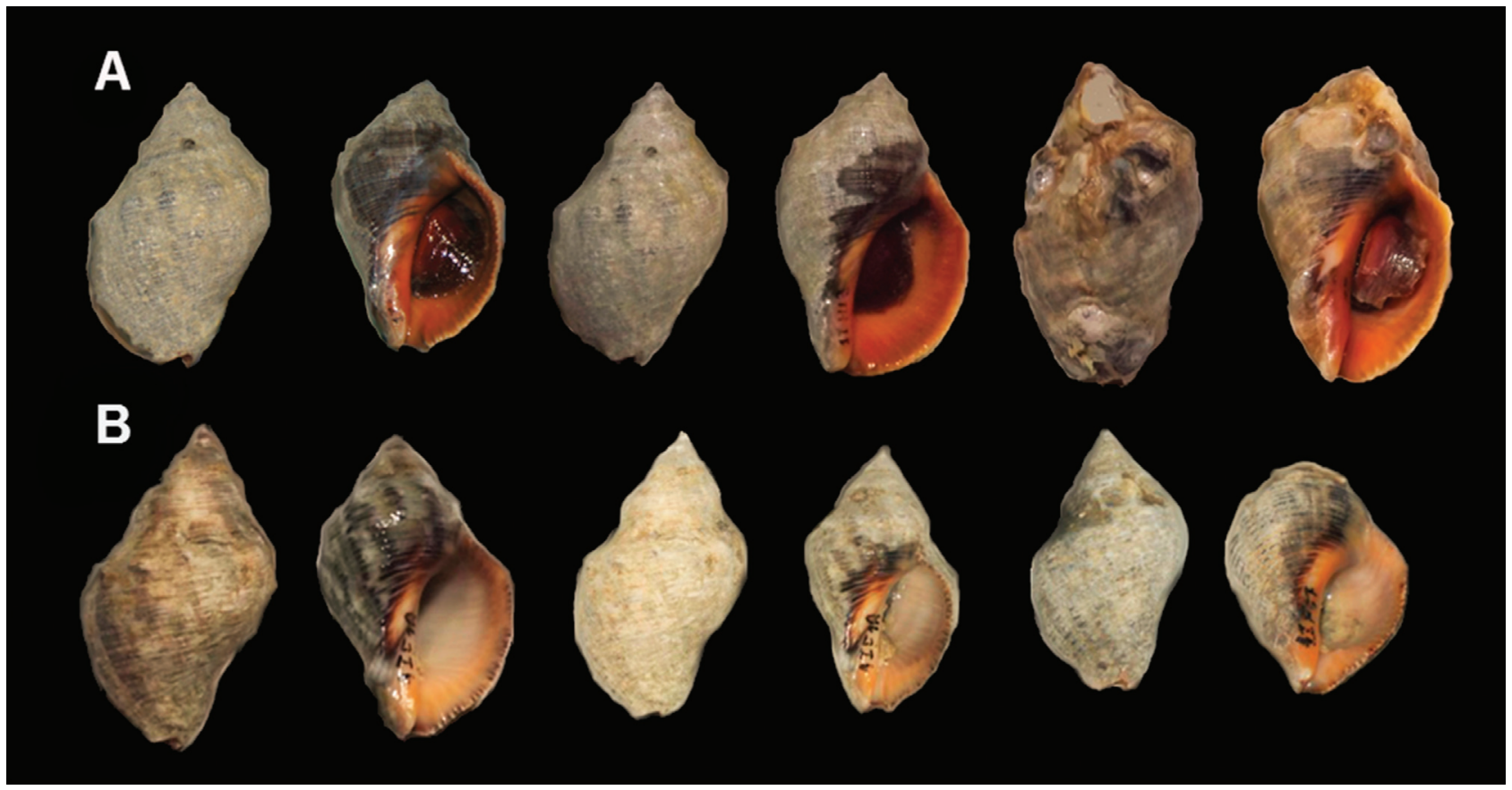

Figure 1 - Color variation and shape of shells of Stramonita cf. haemastoma (A) and S. brasiliensis (B).

quences achieved herein with the sequences of Stramonita type locality worldwide, we used COI and $16 \mathrm{~S}$ sequences of $S$. haemastoma species from Tenerife, Spain (FR695793.1, COI and HE584302.1, 16S), S. floridana from Florida, USA (FR695848.1, COI and HE584301.1, 16S), S. brasiliensis from Ilha Bela, São Paulo, Brazil (FR695844.1, COI and HE584298.1, 16S), and S. rustica from Brazil and Costa Rica (FR695847.1, COI and HE584303.1, 16S).

Forty forward-reverse new partial sequences from 20 specimens were obtained, with a total of $610 \mathrm{bp}$ for the COI gene sequence alignment with nucleotide frequencies and $451 \mathrm{bp}$ for the $16 \mathrm{~S}$ rRNA gene sequence. The conchological variation of Stramonita was not taxonomically informative for species identification (Figure 1). The best evolutionary model was the $\mathrm{HKY}+\mathrm{G}$ (Hasegawa, Kishino and Yano + invariable sites). Analysis of substitutions (transitions and transversions) showed no saturation for either of the two genes. The ML concatenated tree generated from the COI and 16S rRNA gene sequences clustered the Stramonita subspecies into three distinct clades (Figure 2).

There was no genetic distance within clades for $S$. brasiliensis and for $S$. cf. hemastoma collected for this study. The mean genetic divergence between species were: $8 \% \quad(S$. brasiliensis and S. haemastoma), 10\% (S. brasiliensis and S. rustica), and 9\% (S. haemastoma x $S$. rustica). S. floridana (type locality: St Augustine Inlet, St James Co., Florida) diverged genetically from $S$. brasiliensis studied herein by $5 \%$. At the same time, $S$. haemastoma (type locality: Tenerife, Canary Islands) diverged by $2 \%$ from $S$. cf. haemastoma.
In this study, molecular analyses have enabled the detection of strong differences between Stramonita individuals found on the Southeast coast of Brazil, indicating the existence of cryptic variation that is associated with the existence of different species of Stramonita. As reported by Clench (1947), the shells' morphological variations suggest an enormous ambiguity that indicates marked overlay. The reason is that certain environmental factors that intertidal gastropods are exposed to hamper the use of its external morphology for taxonomic identification (Liu et al., 1991; Kool, 1993; Vermeij 2001; Claremont et al., 2011). The two mitochondrial genes used in this study were effective in distinguishing both species as taxonomically distinct units with large genetic distances. A review in the literature about threshold values for molluscs species differentiation shows values between $1.9 \%$ and 14\% (Mikkelsen et al., 2007). Layton et al. (2014), analyzing the COI gene, used the threshold of $2 \%$ to delimitate species of molluscs. Claremont et al. (2011), working with Stramonita, obtained pairwise distances within species of $1.9 \%$ for $S$. rustica, $1.8 \%$ for $S$. haemastoma, $1.3 \%$ for S. floridana, and $0.8 \%$ for $S$. brasiliensis, and sequence divergence among species ranging from $6.8 \%$ to $12.0 \%$. Other genetic and molecular sequences comparison approaches have been used in different studies to identify the occurrence of two sympatric and genetically distinct groups of $S$. haemastoma in Brazil (Udelsmann, 2009, Master of Science Thesis, UNICAMP, Campinas, Brazil). Other methods were used as well to report for the first time the presence of Stramonita haemastoma floridana in the Chesapeake Bay along the southeastern coast of the United States, as a result of iso- 


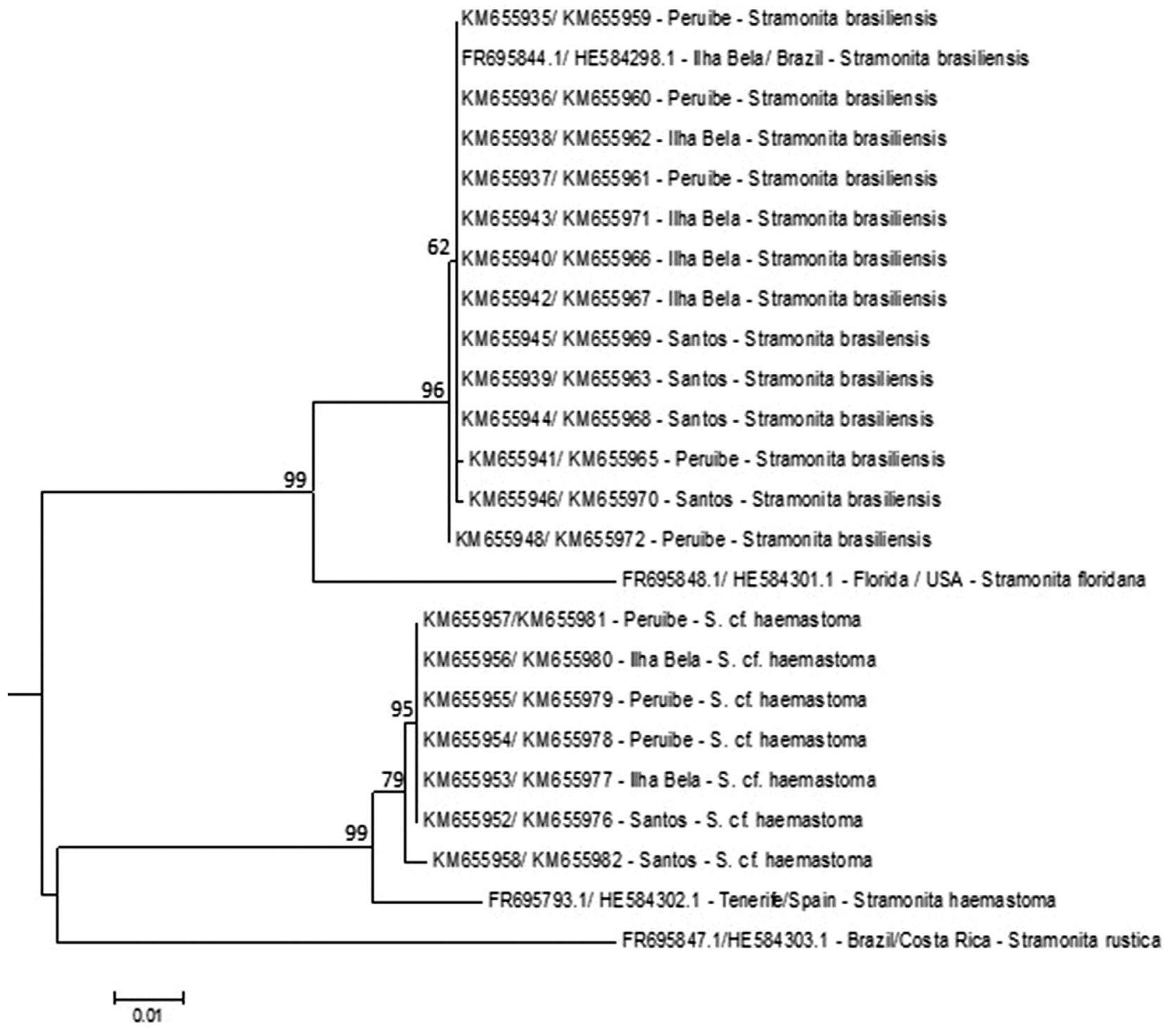

Figure 2 - Maximum Likelihood tree as a result of concatenated data sets of COI and 16S rRNA gene sequences of the Stramonita haemastoma complex. Branches are supported by bootstrap values above $50 \%$. GenBank access numbers and location are shown in Table 1 .

lated introductions or of northward expansions of this species (Harding and Harasewych, 2007).

Our results corroborate the findings of Claremont et al. (2011), which confirm the occurrence of the $S$. brasiliensis along the Brazilian coast. Claremont et al. (2011) also reported that S. floridana only inhabits the south Atlantic region of the United States and suggested that the $S$. rustica species occurs with $S$. brasiliensis along the Brazilian coast. In the present work, we have not verified the presence of $S$. rustica, which is extensively found along the Northeast coast of Brazil (Camillo et al., 2004; Castro et al., 2004). Regarding S. haemastoma, our results showed a genetic distance of $2 \%$ between the $S$. haemastoma from type locality of Tenerife - Spain, clustered with the samples collected for this work. Claremont et al. (2011) pointed out that shells from Brazil have generally been identified as S. haemastoma. These authors, having verified the original descriptions of all names listed as Stramonita species, believe that this species has still to be described. Surprisingly, although these authors collected their samples at the same site as we did our samplings, they did not find specimens other than S. brasiliensis. It is still premature to assert that Stramonita specimens occuring sympatrically with $S$. brasiliensis would be a new species, but $\mathrm{S}$. haemastoma is considered a species complex, and the genetic distance between S. haematoma from Terefine/Spain and from our samples is at the borderline of species delimitation with COI sequence data $(2 \%)$. It is important to point out that the limit of species resolution depends on the model of sequence evolution used. Different 
studies using COI on gastropod species relied on various models, such as Kimura 2-parameter (K2P) distances (Kool and Galindo, 2014; Layton et al., 2014), Generalized time reversible model (GTR $+\mathrm{I}+\Gamma)$ (Pfenninger et al., 2006), and Hasegawa, Kishino and Yano model $(\mathrm{HKY}+\mathrm{I}+\mathrm{G})$ (Claremont et al., 2011). Therefore, we would provisionally identify this species as $S$. cf. haemastoma until further analysis, such as sequence comparison with other genes, cytogenetic studies, internal anatomy, and marginal crenulation evaluations, be carried out for complete taxonomy determination of this taxon.

Finally, Stramonita species represent a food source and their commercial value is potentially high (Manzoni and Lacava, 2010). Therefore, the fishing exploitation of these intertidal marine molluscs can become a profitable business for small-scale coastal fishermen. The challenges in species recognition during fishing can create a serious depauperation, jeopardizing natural populations in Stramonita species. The molecular identification of two independent sympatric taxa cohabiting the same rocky shorelines is an important step for a sustainable management of these species, as their indiscriminate removal for commercial purposes could imperil the ecological balance of the intertidal rocky marine environment.

\section{Acknowledgments}

We would like to thank the São Paulo Research Foundation (FAPESP \# 2011/23752-2) and the Brazilian National Research Council (CNPq \#132712/2010-5) for the financial support of this project. Specimens were collected after authorization provided by ICMBio/SISBIO (license number 24603). This work was developed as part of the requirements for the Master of Science dissertation of J.B. De Biase in Biotechnology at the University of Mogi das Cruzes/Fundação de Amparo ao Ensino e Pesquisa.

\section{References}

Bickford D, Lohman DJ, Sodhi NS, Ng PK, Meier R, Winker K and Das I (2007) Cryptic species as a window on diversity and conservation. Trends Ecol Evol 22:148-155.

Bucklin A, Steinke D and Blanco-Bercial L (2011) DNA barcoding of marine metazoa. Annu Rev Mar Sci 3:471-508.

Butler PA (1985) Synoptic review of the literature on the southern oyster drill Thais haemastoma floridana. NOAA Technical Report NMFS series 35:1-12.

Camillo E, Quadros J, Castro ÍBD and Fernandez M (2004) Imposex in Thais rustica (Mollusca: Neogastropoda) (Lamark, 1822) as an indicator of organotin compounds pollution at Maceio Coast (northeastern Brazil). Braz J Oceanogr 52:101-105.

Castro ÍBD, Meirelles CA, Matthews-Cascon H and Fernandez MA (2004) Thais (Stramonita) rustica (Lamarck, 1822) (Mollusca: Gastropoda: Thaididae), a potential bioindicator of contamination by organotin Northeast Brazil. Braz J Oceanogr 52:135-139.
Claremont M, Williams ST, Barraclough TG and Reid DG (2011) The geographic scale of speciation in a marine snail with high dispersal potential. J Biogeogr 38:1016-1032.

Clench WJ (1947) The genera Purpura and Thais in the Western Atlantic. Johnsonia 2:61-92.

Donald KM, Kennedy M and Spencer HG (2005). The phylogeny and taxonomy of austral monodontine topshells (Mollusca: Gastropoda: trochidae), inferred from DNA sequences. Mol Phylogenet Evol 37:474-483.

Gusmão J, Lazoski C and Solé-Cava AM (2005) Population genetic structure of Brazilian shrimp species (Farfantepenaeus sp., F. brasiliensis, F. paulensis and Litopenaeus schmitti: Decapoda: Penaeidae). Genet Mol Biol 28:165-171.

Harding JM and Harasewych MG (2007) Two new modern records of the southern oyster drill Stramonita haemastoma floridana (Conrad, 1837) in Chesapeake Bay, USA. Nautilus 121:146-158.

Knowlton N (2000) Molecular genetic analyses of species boundaries in the sea. Hydrobiologia 420:73-90.

Kool SP (1993) Phylogenetic analysis of the Rapaninae (Neogastropoda: Muricidae). Malacologia 35:155-259.

Kool HH and Galindo LA (2014) Description and molecular characterization of six new species of Nassarius (Gastropoda, Nassariidae) from the western Pacific Ocean. Amer Malac Bull 32:147-164.

Layton KKS, Martel AL and Hebert PDN (2014) Patterns of DNA barcode variation in Canadian marine molluscs. PLoS One 9:e95003.

Liu LL, Foltz DW and Stickle WB (1991) Genetic population structure of the southern oyster drill Stramonita (=Thais) haemastoma. Mar Biol 111:71-79.

Manzoni GC and Lacava LA (2010) Crescimento dos gastrópodes Thais (Stramonita) haemastoma e Cymatium parthenopeum parthenopeum em cultivo experimental na enseada da armação do Itapocoroy (26O 47 S-48O 36 W) (Penha-SC). Braz J Aquat Sci Technol 2:167-73.

Matthews HR (1968) Notas sobre o gênero Thais Roding, 1798 no Nordeste Brasileiro. Arq Est Biol Mar Univ Fed Ceará 8:37-41.

Meyer CP (2003) Molecular systematics of cowries (Gastropoda: Cypraeidae) and diversification patterns in the tropics. Biol J Linn Soc Lond 79:401-459.

Mikkelsen NT, Schander C and Willassen E (2007). Local scale DNA barcoding of bivalves (Mollusca): A case study. Zool Scr 36:455-463.

Palumbi SR (1996) Nucleic Acids II: The polymerase chain reaction. Mable BK (ed) Molecular Systematics. Sinauer Associates, Sunderland, pp 205-247.

Perez KE and Minton RL (2008). Practical applications for systematics and taxonomy in North American freshwater gastropod conservation. J North Am Benthol Soc 27:471-483.

Pfenninger M, Cordellier M and Streit B (2006) Comparing the efficacy of morphologic and DNA-based taxonomy in the freshwater gastropod genus Radix (Basommatophora, Pulmonata). BMC Evol Biol 6:e100.

Posada D and Crandall KA (1998) MODELTEST: Testing the model of DNA substitution. Bioinformatics 14:817-818.

Ramírez R, Tuya F and Haroun RJ (2009) Spatial patterns in the population structure of the whelk Stramonita haemastoma (Linnaeus, 1766) (Gastropoda: Muricidae) in the Canarian Archipelago (eastern Atlantic). Sci Mar 73:431-437. 
Rios E (1994) Seashells of Brazil. $2^{\text {nd }}$ edition. Fundação da Universidade do Rio Grande, Rio Grande, 331 p.

Rocha LA, Robertson DR, Roman J and Bowen BW (2005) Ecological speciation in tropical reef fishes. Proc R Soc B 272:573-579.

Santos S, Hrbek T, Farias IP, Schneider H and Sampaio I (2006) Population genetic structuring of the king weakfish, Macrodon ancylodon (Sciaenidae), in Atlantic coastal waters of South America: Deep genetic divergence without morphological change. Mol Ecol 15:4361-4373.

Tamura K and Nei M (1993) Estimation of the number of nucleotide substitutions in the control region of mitochondrial DNA in humans and chimpanzees. Mol Biol Evol 10:512526.

Tamura K, Peterson D, Peterson N, Stecher G, Nei M and Kumar S (2011) MEGA5: Molecular evolutionary genetics analysis using maximum likelihood, evolutionary distance, and maximum parsimony methods. Mol Biol Evol 28:2731-2739.

Thorpe JP, Solé-Cava AM and Watts PC (2000) Exploited marine invertebrates: Genetics and fisheries. Hydrobiologia 420:165-184.

Trivedi S, Aloufi AA, Ansari AA and Ghosh SK (2015) Role of DNA barcoding in marine biodiversity assessment and conservation: An update. Saudi J Biol Sci 23:161-171.
Vermeij GJ (2001) Distribution, history, and taxonomy of the Thais clade (Gastripoda: Muricidae) in the Neogene of tropical America. J Paleontol 75:697-705.

Vinson C, Gomes G, Schneider H and Sampaio I (2004) Sciaenidae fish of the Caeté River estuary, Northern Brazil: Mitochondrial DNA suggests explosive radiation for the Western Atlantic assemblage. Genet Mol Biol 27:174-180.

Von der Heyden S, Bowie RCK, Prochazka K, Bloomer P, Crane NL and Bernardi G (2011) Phylogeographic patterns and cryptic speciation across oceanographic barriers in South African intertidal fishes. J Evol Biol 24:2505-2519.

Xia X and Xie Z (2001) DAMBE: Data analysis in molecular biology and evolution. J Hered 92:371-373.

\section{Internet Resources}

Houart R and Gofas S (2010) Stramonita haemastoma (Linnaeus, 1767) World Marine Mollusca database, http://www.marinespecies.org/aphia.php?p=taxdetails\&id= 140417 (accessed March 1, 2013).

Associate Editor: Louis Bernard Klaczko

License information: This is an open-access article distributed under the terms of the Creative Commons Attribution License (type CC-BY), which permits unrestricted use, distribution and reproduction in any medium, provided the original article is properly cited. 